\section{Kidney \\ Blood Pressure Research}

\title{
Negative Regulation of the Creatine Transporter SLC6A8 by SPAK and OSR1
}

\author{
Myriam Fezaia ${ }^{a, b} \quad$ Bernat Elvira $^{a} \quad J^{\prime}$ ose Borras ${ }^{a} \quad$ Mossadok Ben-Attia ${ }^{b}$ \\ Zohreh Hoseinzadeha Florian Lang ${ }^{a}$
}

aDepartment of Physiology I, University of Tübingen, Tübingen, Germany; ${ }^{b}$ Department of Life Sciences LBE(LR01/ES14), Faculty of Sciences of Bizerte, University of Carthage, Tunisia

Key Words

CreaT $•$ Oxidative stress-responsive kinase $1 \cdot$ SPS1-related proline/alanine-rich kinase $\bullet$ WNK

\begin{abstract}
Background/Aims: Transport regulation involves several kinases including SPAK (SPS1related proline/alanine-rich kinase) and OSR1 (oxidative stress-responsive kinase 1), which are under control of WNK (with-no-K[Lys]) kinases. The present study explored whether SPAK and/or OSR1 participate in the regulation of the creatine transporter CreaT (SLC6A8), which accomplishes $\mathrm{Na}^{+}$coupled cellular uptake of creatine in several tissues including kidney, intestine, heart, skeletal muscle and brain. Methods: CRNA encoding SLC6A8 was injected into Xenopus laevis oocytes with or without additional injection of cRNA encoding wild-type SPAK,

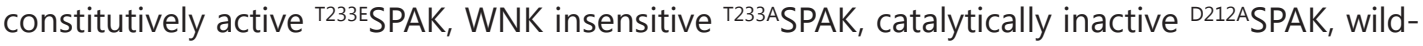
type OSR1, constitutively active ${ }^{T 185 E O S R 1, W N K}$ insensitive ${ }^{\top 185 A}$ OSR1 and catalytically inactive ${ }^{D 164 A}$ OSR1. Transporter activity was determined from creatine $(1 \mathrm{mM})$ induced current utilizing dual electrode voltage clamp. Results: Coexpression of wild-type SPAK and of T233ESPAK, but not of T233ASPAK or of D212ASPAK was followed by a significant decrease of creatine induced current in SLC6A8 expressing oocytes. Coexpression of SPAK significantly decreased maximal transport rate. Coexpression of wild-type OSR1, ${ }^{\top 185 E O S R} 1$ and ${ }^{\top 185 A} \mathrm{OSR} 1$ but not of ${ }^{\mathrm{D} 164 \mathrm{~A} O S R 1}$ significantly negatively regulated SLC6A8 activity. OSR1 again decreased significantly maximal transport rate. Conclusions: Both, SPAK and OSR1, are negative regulators of the creatine transporter SLC6A8.
\end{abstract}

Copyright $(2014$ S. Karger AG, Basel

\section{Introduction}

With-no-K[Lys] kinases (WNK) [1-5] and their downstream kinases SPS1-related proline/alanine-rich kinase (SPAK) $[1,6,7]$ and oxidative stress-responsive kinase 1 (OSR1) $[8,9]$ participate in the regulation of transport and blood pressure [10-14]. Both, SPAK and 


\section{Kidney \\ Blood Pressure Research}

\section{Kidney Blood Press Res 2014;39:546-554}

\begin{tabular}{l|l}
\hline DOI: $10.1159 / 000368465$ & C 2014 S. Karger AG, Basel
\end{tabular}

Publisned onIIne: December 082014

www.karger.com/kbr

Fezai/Elvira/Borras/Ben-Attia/Hoseinzadeh/Lang: SPAK/OSR1 Negatively Regulate CreaT

OSR1 up-regulate the $\mathrm{Na}^{+}, \mathrm{Cl}^{-}$(NCC) and $\mathrm{Na}^{+}, \mathrm{K}^{+}, 2 \mathrm{Cl}^{-}$(NKCC) cotransporters [2, 3, 8-10, 15 23] as well as $\mathrm{Na}^{+}$coupled phosphate transport [24]. Genetic defects affecting the activity of WNK kinases may lead to Gordon's syndrome, a monogenic disorder characterized by hyperkalaemia and hypertension $[4,5,25,26]$. SPAK/OSR1 participates in a wide variety of further functions including neuroexcitability [27-29].

To the best of our knowledge, nothing is known about effects of WNK, SPAK and/or OSR1 on the activity of the creatine transporter CreaT (SLC6A8), a member of the superfamily of $\mathrm{Na}^{+}, \mathrm{Cl}^{-}$coupled transporters for neurotransmitters [30-32] and organic osmolytes [33, 34]. SLC6A8 is expressed in a wide variety of tissues, such as kidney, small intestine, heart, skeletal muscle, brain and retina [35-38]. Genetic disorders affecting SLC6A8 lead to mental retardation with seizures [39-56].

In order to test whether SPAK or OSR1 may influence SLC6A8 activity, cRNA encoding SLC6A8 was injected into Xenopus laevis oocytes without or with additional injection of cRNA encoding SPAK or OSR1. The creatine induced current was determined utilizing dual electrode voltage clamp.

\section{Materials and Methods}

\section{Ethical Statement}

All experiments conform with the 'European Convention for the Protection of Vertebrate Animals used for Experimental and other Scientific Purposes' (Council of Europe No 123, Strasbourg 1985) and were conducted according to the German law for the welfare of animals.

\section{Constructs}

Constructs encoding bovine wild-type SLC6A8 (CreaT) [31], human wild-type SPAK, constitutively

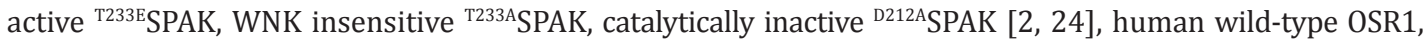
constitutively active ${ }^{\mathrm{T} 185 \mathrm{E}} \mathrm{OSR} 1$, WNK insensitive ${ }^{\mathrm{T} 185 \mathrm{~A}} \mathrm{OSR} 1$ and catalytically inactive ${ }^{\mathrm{D} 164 \mathrm{~A}} \mathrm{OSR} 1$ [57] were used for generation of cRNA as described previously [58,59]. The constructs were a kind gift from Dario Alessi (University of Dundee).

\section{Voltage clamp in Xenopus laevis oocytes}

Xenopus laevis oocytes were prepared as previously described [60,61]. 15 ng cRNA encoding SLC6A8 and 10 ng of cRNA encoding wild-type, constitutively active, WNK insensitive or inactive kinase of either SPAK or OSR1 were injected on the same day after preparation of the oocytes. The oocytes were stored at $17^{\circ} \mathrm{C}$ in incubation medium ND96, a solution containing $88.5 \mathrm{mM} \mathrm{NaCl}, 2 \mathrm{mM} \mathrm{KCl}, 1.8 \mathrm{mM} \mathrm{CaCl}_{2}$, $1 \mathrm{mM} \mathrm{MgCl}{ }_{2}, 5 \mathrm{mM}$ HEPES, $2.5 \mathrm{mM} \mathrm{NaOH}$ and $5 \mathrm{mM}$ sodium pyruvate $\left(\mathrm{C}_{3} \mathrm{H}_{3} \mathrm{NaO}_{3}\right)$, supplemented with 100 mg/l Gentamycin, $50 \mathrm{mg} / \mathrm{l}$ Tetracycline, $1.6 \mathrm{mg} / \mathrm{l}$ Ciprofloxacin and $90 \mathrm{mg} / \mathrm{l}$ Theophiline (pH 7.4). [62, 63]. Solutions were sterilized through $0.22 \mu \mathrm{m}$ filter. The voltage clamp experiments were performed at room temperature 4 days after the first injection $[64,65]$. Carrier activity was estimated from substrate ( $1 \mathrm{mM}$ creatine) induced current at a holding potential of $-60 \mathrm{mV}$ [66]. The data were filtered at $10 \mathrm{~Hz}$ and recorded with a Digidata A/D-D/A converter (1322A Axon Instruments) and Clampex 9.2 software for data acquisition and analysis (Axon Instruments) [67-69]. The oocytes recording chamber was continuously perfused with control ND96 solution containing (in mM): $93.5 \mathrm{NaCl}, 2 \mathrm{KCl}, 1.8 \mathrm{CaCl}_{2}, 1 \mathrm{MgCl}_{2}, 5 \mathrm{HEPES}$, $2.5 \mathrm{NaOH}$ (pH 7.4). The flow rate of the superfusion was approx. $20 \mathrm{ml} / \mathrm{min}$, and a complete exchange of the bath solution was reached within about $10 \mathrm{~s}$ [70-72]. For kinetic analysis the creatine induced-current $\left(\mathrm{I}_{\text {creat }}\right)$ was plotted against the respective creatine concentration $(s)$ and maximal current $\left(\mathrm{I}_{\max }\right)$ as well as concentration required for halfmaximal current $\left(k_{m}\right)$ calculated using the equation $\mathrm{I}_{\text {Crea }}=\mathrm{I}_{\text {max }} \cdot \mathrm{s} /\left(\mathrm{k}_{\mathrm{m}}+\mathrm{s}\right)$.

\section{Statistical analysis}

Data are provided as means \pm SEM, $n$ represents the number of oocytes investigated [73]. All voltage clamp experiments were repeated with at least 3 batches of oocytes; in all repetitions qualitatively similar data were obtained. Data were tested for significance using ANOVA or t-test, as appropriate. Results with $\mathrm{p}<0.05$ were considered statistically significant. 


\section{Kidney Blood Pressure Research}

Kidney Blood Press Res 2014;39:546-554

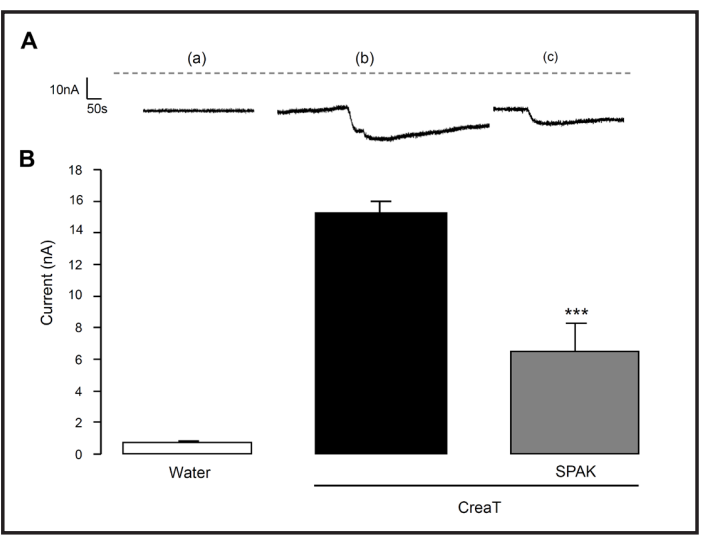

Fig. 1. Coexpression of SPAK decreases electrogenic creatine transport in SLC6A8 expressing Xenopus laevis oocytes. A: Representative original tracings showing creatine $(1 \mathrm{mM})$ - induced current ( $\left.\mathrm{I}_{\text {creat }}\right)$ in Xenopus laevis oocytes injected with water (a) or expressing SLC6A8 without (b) or with (c) additional coexpression of wild-type SPAK. B: Arithmetic means \pm SEM $(n=11-23)$ of $\mathrm{I}_{\text {creat }}$ in Xenopus laevis oocytes injected with water (white bar), or expressing SLC6A8 without (black bar) or with wild-type SPAK (grey bar). ${ }^{* * *}(\mathrm{p}<0.001)$ indicates statistically significant difference from the absence of SPAK.

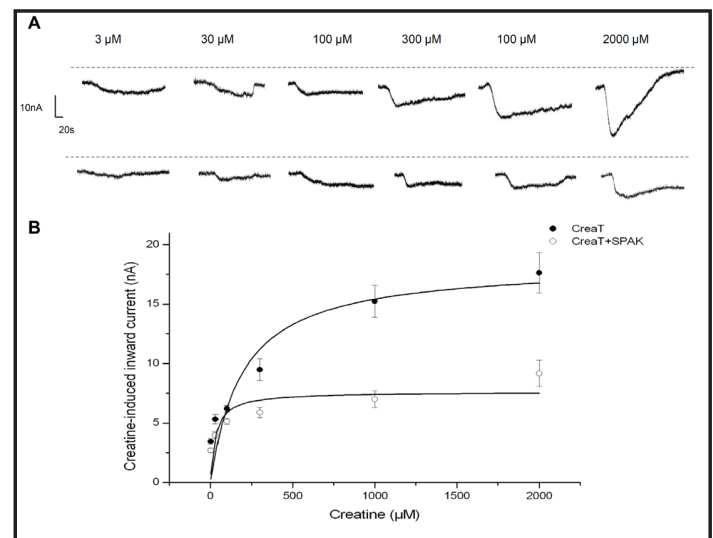

Fig. 2. Coexpression of SPAK decreases maximal electrogenic creatine transport in SLC6A8-expressing Xenopus laevis oocytes. A: Representative original tracings showing the current induced by increasing concentrations of creatine (from $3 \mu \mathrm{M}$ to $2 \mathrm{mM}$ ) in Xenopus laevis oocytes expressing SLC6A8 without (upper panel) or with (lower panel) additional coexpression of wild-type SPAK. B: Arithmetic means \pm SEM ( $n=6-8)$ of $I_{\text {creat }}$ as a function of creatine concentration in Xenopus laevis oocytes expressing SLC6A8 without (black circles), or with (white circles) additional coexpression of wild-type SPAK.

\section{Results}

The present study explored whether SPAK (SPS1-related proline/alanine-rich kinase) and/or OSR1 (oxidative stress-responsive kinase 1) are able to modify the function of the creatine transporter CreaT (SLC6A8). To this end, cRNA encoding SLC6A8 was injected into Xenopus laevis oocytes with or without additional injection of cRNA encoding wildtype SPAK, mutant SPAK, wild-type OSR1 or mutant OSR1. Creatine induced-current (I creat $_{\text {) }}$ was determined utilizing dual electrode voltage clamp. As shown in Fig. 1, no appreciable current was observed in water-injected oocytes indicating that the oocytes did not express significant endogenous electrogenic creatine transport. Creatine exposure of SLC6A8 expressing oocytes was, however followed by a sizable $\mathrm{I}_{\text {creat }}$. The additional coexpression of wild-type SPAK significantly decreased the $\mathrm{I}_{\text {creat }}$ in SLC6A8 expressing Xenopus laevis oocytes.

In order to determine whether SPAK coexpression modifies the maximal $I_{\text {creat }}$ or the affinity of the carrier, Xenopus laevis oocytes expressing SLC6A8 without or with additional expression of SPAK were exposed to creatine at concentrations ranging from $3 \mu \mathrm{M}$ to $2 \mathrm{mM}$. As illustrated in Fig. 2, the $\mathrm{I}_{\text {creat }}$ was a function of the extracellular creatine concentration. Kinetic analysis revealed that the maximal creatine induced current was significantly $(\mathrm{p}<0.01)$ higher in Xenopus laevis oocytes expressing SLC6A8 alone $(18.4 \pm 2.6 \mathrm{nA}, \mathrm{n}=6-8)$ than in Xenopus laevis oocytes expressing SLC6A8 together with SPAK $(7.6 \pm 1.0 \mathrm{nA}, \mathrm{n}=6-7)$. The concentration required for halfmaximal creatine induced current was highly variable and not significantly different between Xenopus laevis oocytes expressing SLC6A8 alone (192 $\pm 102 \mathrm{mM}, \mathrm{n}=6-8)$ and Xenopus laevis oocytes expressing SLC6A8 together with SPAK $(29 \pm 22 \mathrm{mM}, \mathrm{n}=6-7)$.

Further experiments explored the effect of SPAK mutants on the $\mathrm{I}_{\text {creat }}$ in SLC6A8 expressing Xenopus laevis oocytes. To this end the SPAK mutants were coexpressed in SLC6A8 expressing Xenopus oocytes. As illustrated in Fig. 3, the effect of wild-type SPAK was 


\section{Kidney \\ Blood Pressure \\ Research}

\section{Kidney Blood Press Res 2014;39:546-554}

\begin{tabular}{l|l}
\hline DOI: 10.1159/000368465 & C 2014 S. Karger AG, Basel
\end{tabular}

Publisned onIIne: December 082014

www.karger.com/kbr CreaT

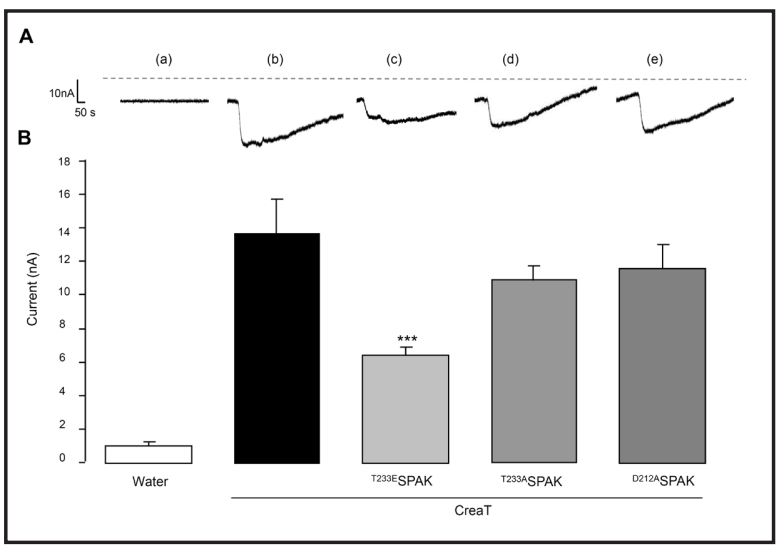

Fig. 3. The effect of SPAK on SLC6A8 is mimicked by active

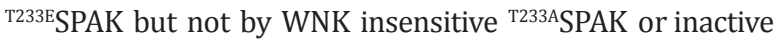
${ }^{\mathrm{D} 212 \mathrm{~A}} \mathrm{SPAK}$. A: Representative original tracings showing $\mathrm{I}_{\text {creat }}$ in Xenopus laevis oocytes injected with water (a), or expressing SLC6A8 without (b) or with additional coexpression of constitutively active T233ESPAK (c), WNK1 insensi-

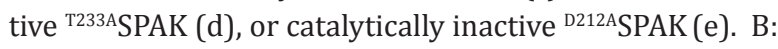
Arithmetic means \pm SEM $(\mathrm{n}=12-30)$ of $\mathrm{I}_{\text {creat }}$ in Xenopus laevis oocytes injected with water (white bar), or expressing SLC6A8 without (black bar) or with constitutively ac-

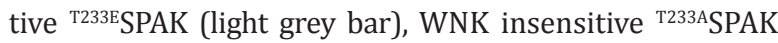

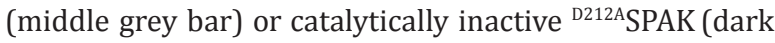
grey bar). ${ }^{* * *}(\mathrm{p}<0.001$, indicates statistically significant difference from oocytes expressing SLC6A8 alone.

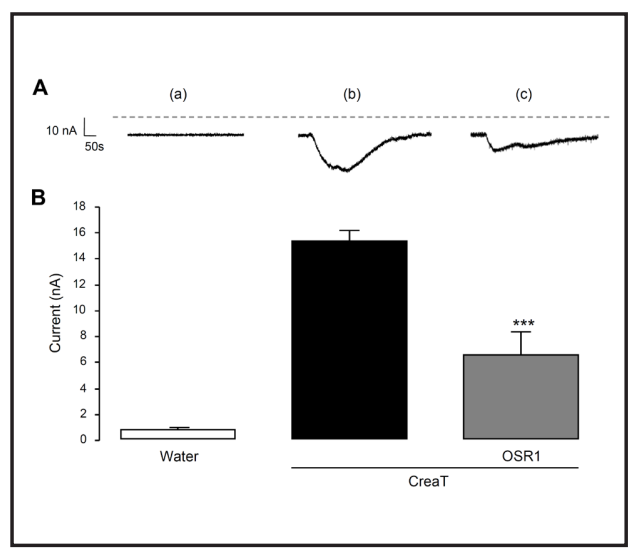

Fig. 4. Coexpression of OSR1 decreases electrogenic creatine transport in SLC6A8 expressing Xenopus laevis oocytes. A: Representative original tracings showing $\mathrm{I}_{\text {creat }}$ in Xenopus laevis oocytes injected with water (a) or expressing SLC6A8 without (b) or with (c) additional coexpression of wild-type OSR1. B: Arithmetic means \pm SEM $(n=10-30)$ of $I_{\text {creat }}$ in Xenopus laevis oocytes injected with water (white bar), or expressing SLC6A8 without (black bar) or with (grey bar) wild-type 0SR1. *** $(\mathrm{p}<0.001$, indicates statistically significant difference from the absence of OSR1.

Fig. 5. Coexpression of OSR1 decreases maximal electrogenic creatine transport in SLC6A8 -expressing Xenopus laevis oocytes. A: Representative original tracings showing the current induced by increasing concentrations of creatine (from 3 $\mu \mathrm{M}$ to $2 \mathrm{mM}$ ) in Xenopus laevis oocytes expressing SLC6A8 without (upper panel) or with (lower panel) additional coexpression of wild-type OSR1. B: Arithmetic means \pm SEM ( $n=5-7)$ of $I_{\text {creat }}$ as a function of creatine concentration in Xenopus laevis oocytes expressing SLC6A8 without (black circles), or with (white circles) additional coexpression of wild-type OSR1.

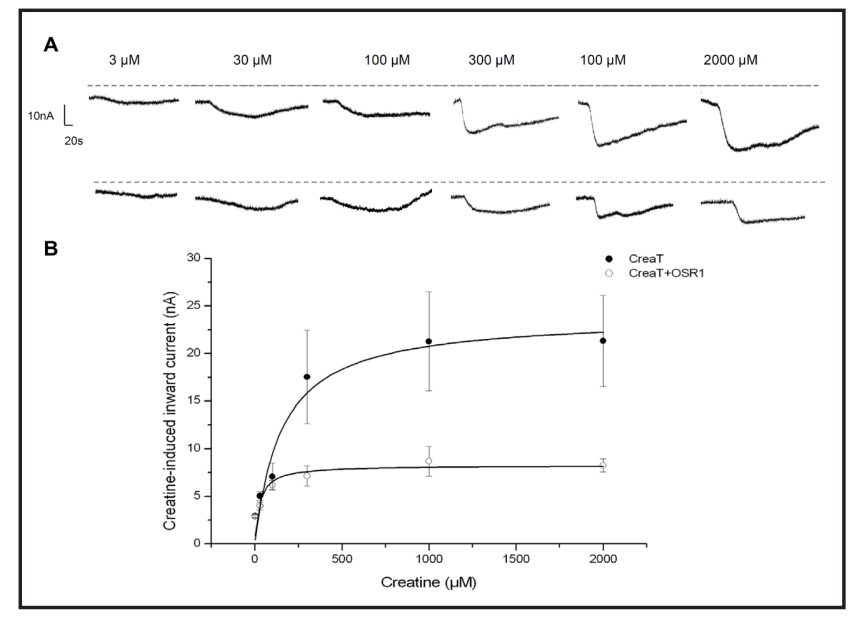

mimicked by the constitutively active ${ }^{\text {T233E }}$ SPAK but neither by the WNK insensitive ${ }^{\text {T233ASPAK }}$ nor by the catalytically inactive ${ }^{\mathrm{D} 212 \mathrm{~A}} \mathrm{SPAK}$. Coexpression of ${ }^{\mathrm{T} 233 \mathrm{E}} \mathrm{SPAK}$ significantly decreased the $\mathrm{I}_{\text {creat }}$ in SLC6A8 expressing oocytes.

Further experiments addressed the effect of OSR1 on SLC6A8 activity. As shown in Fig. 4 , the additional coexpression of wild-type OSR1 significantly decreased the I ${ }_{\text {creat }}$ in SLC6A8 expressing Xenopus laevis oocytes.

Fig. 5 displays the $I_{\text {creat }}$ as a function of the extracellular creatine concentration in Xenopus oocytes expressing SLC6A8 alone and in Xenopus laevis oocytes expressing SLC6A8 together 


\section{Kidney \\ Blood Pressure Research}

Kidney Blood Press Res 2014;39:546-554

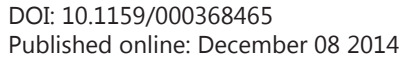

(C) 2014 S. Karger AG, Basel

www.karger.com/kbr

CreaT

Fig. 6. The effect of OSR1 on SLC6A8 is mimicked by active ${ }^{\mathrm{T} 185 \mathrm{E}}$ OSR1 and WNK insensitive ${ }^{\mathrm{T} 185 \mathrm{~A}}$ OSR1 but not by inactive ${ }^{\mathrm{D} 164 \mathrm{~A}}$ OSR1. A: Representative original tracings showing $\mathrm{I}_{\text {creat }}$ in Xenopus laevis oocytes injected with water (a), or expressing SLC6A8 without (b) or with additional coexpression of constitutively

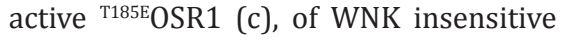
${ }^{\mathrm{T} 185 \mathrm{~A}}$ OSR1 (d) or of catalytically inactive ${ }^{\mathrm{D} 164 \mathrm{~A}}$ OSR1 (e). B: Arithmetic means \pm SEM $(\mathrm{n}=15-20)$ of $\mathrm{I}_{\text {creat }}$ in Xenopus laevis oocytes injected with water (white bar), or expressing SLC6A8 without (black bar) or with constitutively active ${ }^{\mathrm{T} 185 \mathrm{E}} \mathrm{OSR} 1$

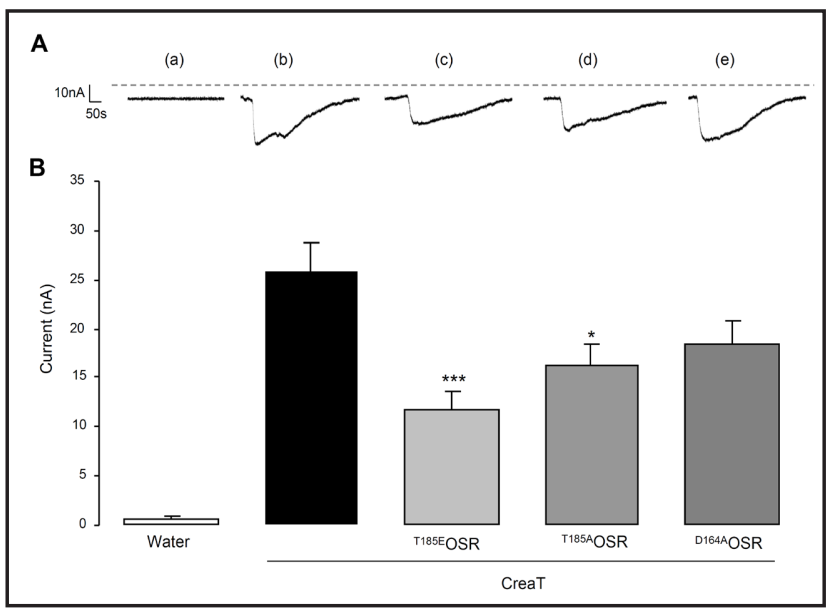
(light grey bar), with WNK insensitive ${ }^{\mathrm{T} 185 \mathrm{~A}}$ OSR1 (middle grey bar) or with catalytically inactive ${ }^{\mathrm{D} 164 \mathrm{~A}}$ OSR1 (dark grey bar). ${ }^{*}(\mathrm{p}<0.05),{ }^{* * *}(\mathrm{p}<0.001)$ indicates statistically significant difference from oocytes expressing SLC6A8 alone.

with OSR1. Kinetic analysis revealed that the maximal $I_{\text {creat }}$ was significantly $(p<0.001)$ higher in Xenopus laevis oocytes expressing SLC6A8 alone (23.9 $\pm 2.1 \mathrm{nA}, \mathrm{n}=5-6)$ than in Xenopus laevis oocytes expressing SLC6A8 together with OSR1 $(8.2 \pm 0.7 \mathrm{nA}, \mathrm{n}=7)$. The concentration required for halfmaximal creatine induced current was significantly higher in Xenopus oocytes expressing SLC6A8 alone $(152 \pm 53 \mathrm{mM}, \mathrm{n}=5-6)$ than in Xenopus oocytes expressing SLC6A8 together with OSR1 $(26 \pm 14 \mathrm{mM}, \mathrm{n}=7)(\mathrm{p}<0.05)$.

As illustrated in Fig. 6, the effect of wild-type OSR1 was mimicked by constitutively active ${ }^{\mathrm{T} 185 \mathrm{E}}$ OSR1 and less by WNK insensitive ${ }^{\mathrm{T} 185 \mathrm{~A}}$ OSR1 but not by the catalytically inactive ${ }^{\mathrm{D} 164 \mathrm{~A}}$ OSR1.

\section{Discussion}

The present study discloses a novel function of SPAK and OSR1, i.e. the negative regulation of the creatine transporter SLC6A8. Coexpression of SPAK or OSR1 is followed by a decrease of the maximal creatine transport in SLC6A8 expressing oocytes. Transporters similarly negatively regulated by SPAK and OSR1 include $\mathrm{KCl}$ cotransporters [27, 74]. On the other hand SPAK and OSR1 positively regulate the $\mathrm{Na}^{+}, \mathrm{Cl}^{-}(\mathrm{NCC})$ and $\mathrm{Na}^{+}, \mathrm{K}^{+}, 2 \mathrm{Cl}^{-}$ (NKCC) cotransporters [2, 3, 8-10, 15-23] as well as $\mathrm{Na}^{+}$coupled phosphate transport [24]. The molecular requirements for negative or positive regulation by SPAK and OSR1 are incompletely understood.

The effect of wild type SPAK and OSR1 on SLC6A8 activity was mimicked by the constitutively active mutants. SLC6A8 activity was not affected by the kinase dead mutants, indicating that functional kinases are required for the SPAK/OSR1 sensitive regulation of

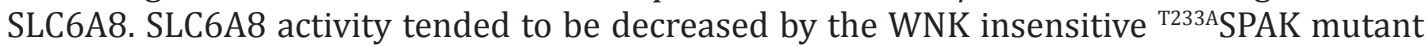
and was significantly decreased by the WNKinsensitive ${ }^{\mathrm{T} 185 \mathrm{~A}}$ OSR1 mutant. Those observations could point to some WNK independent activity of SPAK and/or OSR1. The observations do not necessarily indicate that the carrier is directly phosphorylated by the kinases. Instead, the kinases could phosphorylate and thus modify the function of other signaling molecules involved in the regulation of the carrier.

The present study did not address the in vivo significance of SPAK/OSR1 sensitive creatine transport activity. The carrier plays an important role in the regulation of neuronal function and neuroexcitability [39-56]. The WNK-SPAK/OSR1 kinase pathway is similarly 


\title{
Kidney \\ Blood Pressure Research
}

\author{
Kidney Blood Press Res 2014;39:546-554 \\ \begin{tabular}{l|l}
\hline DOI: $10.1159 / 000368465$ & (c) 2014 S. Karger AG, Basel
\end{tabular} \\ Publisned online: vecember 082014 \\ www.karger.com/kbr \\ Fezai/Elvira/Borras/Ben-Attia/Hoseinzadeh/Lang: SPAK/OSR1 Negatively Regulate \\ CreaT
}

involved in the regulation of neuronal excitation [27, 74]. SPAK/OSR1 modify, however, neuroexcitability at least in part by activation of NKCC dependent $\mathrm{Cl}^{-}$uptake and inhibition of KCC dependent $\mathrm{Cl}^{-}$exit leading to increase of intracellular chloride concentration $[27,74]$. The intracellular $\mathrm{Cl}^{-}$concentration is in turn a critical determinant of the effects of GABA on cell membrane potential and neuronal excitation [27, 74]. WNK kinases are activated following decrease of intracellular $\mathrm{Cl}^{-}$concentration and they trigger cellular $\mathrm{Cl}^{-}$uptake by activating SPAK/OSR1 [27]. Disorders involving deranged SPAK/OSR activity include arterial hypertension and enhanced neuronal activity leading to epilepsy, spasticity, neuropathic pain, schizophrenia, and autism [27].

SPAK/OSR1 further contribute to cell volume regulation by triggering cellular $\mathrm{NaCl}$ uptake due to activation of the $\mathrm{Na}^{+}, \mathrm{Cl}^{-}$cotransporter and the $\mathrm{Na}^{+}, \mathrm{K}^{+}, 2 \mathrm{Cl}^{-}$cotransporter $[2$, $3,8-10,15-23]$. We do not know, whether SLC6A8 is regulated by cell volume. The SLC6A8 related organic osmolyte transporters are up-regulated rather than negatively regulated by cell shrinkage $[33,34]$.

\section{Conclusion}

SPAK and OSR1 are capable to negatively regulate the creatine transporter SLC6A8.

\section{Disclosure Statement}

The authors of this manuscript state that they do not have any conflict of interests and have nothing to disclose.

\section{Acknowledgements}

The authors acknowledge the meticulous preparation of the manuscript by Lejla Subasic and technical support by Elfriede Faber. This study was supported by the Deutsche Forschungsgemeinschaft, GRK 1302, SFB 773 B4/A1, La 315/13-3, and the Open Access Publishing Fund of Tuebingen University. MF was supported by the Tunisian ministry of higher education and scientific research.

\section{References}

1 Rafiqi FH, Zuber AM, Glover M, Richardson C, Fleming S, Jovanovic S, Jovanovic A, O'Shaughnessy KM, Alessi DR: Role of the WNK-activated SPAK kinase in regulating blood pressure. EMBO Mol Med 2010;2:63-75.

2 Vitari AC, Deak M, Morrice NA, Alessi DR: The WNK1 and WNK4 protein kinases that are mutated in Gordon's hypertension syndrome phosphorylate and activate SPAK and OSR1 protein kinases. Biochem J 2005;391:17-24.

-3 Vitari AC, Thastrup J, Rafiqi FH, Deak M, Morrice NA, Karlsson HK, Alessi DR: Functional interactions of the SPAK/OSR1 kinases with their upstream activator WNK1 and downstream substrate NKCC1. Biochem J 2006;397:223-231.

4 Glover M, Zuber AM, O'Shaughnessy KM: Hypertension, dietary salt intake, and the role of the thiazidesensitive sodium chloride transporter NCCT. Cardiovasc Ther 2011;29:68-76.

5 O'Reilly M, Marshall E, Speirs HJ, Brown RW: WNK1, a gene within a novel blood pressure control pathway, tissue-specifically generates radically different isoforms with and without a kinase domain. J Am Soc Nephrol 2003;14:2447-2456.

-6 Castaneda-Bueno M, Gamba G: SPAKling insight into blood pressure regulation. EMBO Mol Med 2010;2:3941. 


\section{Kidney \\ Blood Pressure Research}

\begin{tabular}{|c|c|}
\hline Kidney Blood Press Res 2014 & \\
\hline $\begin{array}{l}\text { DOI: } 10.1159 / 000368465 \\
\text { Published onlIne: December } 082014\end{array}$ & $\begin{array}{l}\text { (C) } 2014 \text { S. Karger AG, Basel } \\
\text { www.karger.com/kbr }\end{array}$ \\
\hline
\end{tabular}

7 Yang SS, Lo YF, Wu CC, Lin SW, Yeh CJ, Chu P, Sytwu HK, Uchida S, Sasaki S, Lin SH: SPAK-knockout mice manifest Gitelman syndrome and impaired vasoconstriction. J Am Soc Nephrol 2010;21:1868-1877.

-8 Lin SH, Yu IS, Jiang ST, Lin SW, Chu P, Chen A, Sytwu HK, Sohara E, Uchida S, Sasaki S, Yang SS: Impaired phosphorylation of $\mathrm{Na}(+)-\mathrm{K}(+)-2 \mathrm{Cl}(-)$ cotransporter by oxidative stress-responsive kinase-1 deficiency manifests hypotension and Bartter-like syndrome. Proc Natl Acad Sci USA 2011;108:17538-17543.

-9Villa F, Deak M, Alessi DR, van Aalten DM: Structure of the OSR1 kinase, a hypertension drug target. Proteins 2008;73:1082-1087.

10 Kahle KT, Rinehart J, Lifton RP: Phosphoregulation of the Na-K-2Cl and K-Cl cotransporters by the WNK kinases. Biochim Biophys Acta 2010;1802:1150-1158.

11 Flatman PW: Cotransporters, WNKs and hypertension: an update. Curr Opin Nephrol Hypertens 2008;17:186-192.

12 Furgeson SB, Linas S: Mechanisms of type I and type II pseudohypoaldosteronism. J Am Soc Nephrol 2010;21:1842-1845.

13 Uchida S: Pathophysiological roles of WNK kinases in the kidney. Pflugers Arch 2010;460:695-702.

14 Wilson FH, Disse-Nicodeme S, Choate KA, Ishikawa K, Nelson-Williams C, Desitter I, Gunel M, Milford DV, Lipkin GW, Achard JM, Feely MP, Dussol B, Berland Y, Unwin RJ, Mayan H, Simon DB, Farfel Z, Jeunemaitre X, Lifton RP: Human hypertension caused by mutations in WNK kinases. Science 2001;293:1107-1112.

15 Delpire E, Gagnon KB: SPAK and OSR1, key kinases involved in the regulation of chloride transport. Acta Physiol (Oxf) 2006;187:103-113.

16 Delpire E, Gagnon KB: SPAK and OSR1: STE20 kinases involved in the regulation of ion homoeostasis and volume control in mammalian cells. Biochem J 2008;409:321-331.

17 Gimenez I: Molecular mechanisms and regulation of furosemide-sensitive $\mathrm{Na}-\mathrm{K}-\mathrm{Cl}$ cotransporters. Curr Opin Nephrol Hypertens 2006;15:517-523.

18 Richardson C, Sakamoto K, de los Heros P, Deak M, Campbell DG, Prescott AR, Alessi DR: Regulation of the NKCC2 ion cotransporter by SPAK-OSR1-dependent and -independent pathways. J Cell Sci 2011;124:789800.

19 Gagnon KB, Delpire E: On the substrate recognition and negative regulation of SPAK, a kinase modulating Na+-K+-2Cl- cotransport activity. Am J Physiol Cell Physiol 2010;299:C614-C620.

20 Glover M, O'Shaughnessy KM: SPAK and WNK kinases: a new target for blood pressure treatment? Curr Opin Nephrol Hypertens 2011;20:16-22.

21 Huang CL, Yang SS, Lin SH: Mechanism of regulation of renal ion transport by WNK kinases. Curr Opin Nephrol Hypertens 2008;17:519-525.

22 Mercier-Zuber A, O'Shaughnessy KM: Role of SPAK and OSR1 signalling in the regulation of $\mathrm{NaCl}$ cotransporters. Curr Opin Nephrol Hypertens 2011;20:534-540.

-23 Richardson C, Alessi DR: The regulation of salt transport and blood pressure by the WNK-SPAK/OSR1 signalling pathway. J Cell Sci 2008;121:3293-3304.

-24 Pathare G, Foller M, Michael D, Walker B, Hierlmeier M, Mannheim JG, Pichler BJ, Lang F: Enhanced FGF23 serum concentrations and phosphaturia in gene targeted mice expressing WNK-resistant SPAK. Kidney Blood Press Res 2012;36:355-364.

25 Achard JM, Disse-Nicodeme S, Fiquet-Kempf B, Jeunemaitre X: Phenotypic and genetic heterogeneity of familial hyperkalaemic hypertension (Gordon syndrome). Clin Exp Pharmacol Physiol 2001;28:1048-1052.

-26 Capasso G, Cantone A, Evangelista C, Zacchia M, Trepiccione F, Acone D, Rizzo M: Channels, carriers, and pumps in the pathogenesis of sodium-sensitive hypertension. Semin Nephrol 2005;25:419-424.

27 Alessi DR, Zhang J, Khanna A, Hochdorfer T, Shang Y, Kahle KT: The WNK-SPAK/OSR1 pathway: master regulator of cation-chloride cotransporters. Sci Signal 2014;7:re3.

-28 Gagnon KB, Delpire E: Molecular physiology of SPAK and OSR1: two Ste20-related protein kinases regulating ion transport. Physiol Rev 2012;92:1577-1617.

29 Gagnon KB, Di Fulvio M: A molecular analysis of the $\mathrm{Na(+)-independent} \mathrm{cation} \mathrm{chloride} \mathrm{cotransporters.} \mathrm{Cell}$ Physiol Biochem 2013;32:14-31.

-30 Christie DL: Functional insights into the creatine transporter. Subcell Biochem 2007;46:99-118.

-31 Dodd JR, Christie DL: Cysteine 144 in the third transmembrane domain of the creatine transporter is located close to a substrate-binding site. J Biol Chem 2001;276:46983-46988.

-32 Sora I, Richman J, Santoro G, Wei H, Wang Y, Vanderah T, Horvath R, Nguyen M, Waite S, Roeske WR, et al.: The cloning and expression of a human creatine transporter. Biochem Biophys Res Commun 1994;204:419-427. 


\section{Kidney \\ Blood Pressure Research}

Kidney Blood Press Res 2014;39:546-554

\begin{tabular}{l|l}
\hline DOI: $10.1159 / 000368465$ & $\begin{array}{l}\text { C 2014 S. Karger AG, Basel } \\
\text { Publisned ontIne: December } 082014\end{array}$ \\
www.karger.com/kbr
\end{tabular}

Fezai/Elvira/Borras/Ben-Attia/Hoseinzadeh/Lang: SPAK/OSR1 Negatively Regulate CreaT

-33 Takenaka M, Bagnasco SM, Preston AS, Uchida S, Yamauchi A, Kwon HM, Handler JS: The canine betaine gamma-amino-n-butyric acid transporter gene: diverse mRNA isoforms are regulated by hypertonicity and are expressed in a tissue-specific manner. Proc Natl Acad Sci USA 1995;92:1072-1076.

34 Uchida S, Kwon HM, Yamauchi A, Preston AS, Marumo F, Handler JS: Molecular cloning of the cDNA for an MDCK cell $\mathrm{Na}(+)$ - and $\mathrm{Cl}(-)$-dependent taurine transporter that is regulated by hypertonicity. Proc Natl Acad Sci USA 1992;89:8230-8234.

-35 Braissant 0, Henry H: AGAT, GAMT and SLC6A8 distribution in the central nervous system, in relation to creatine deficiency syndromes: a review. J Inherit Metab Dis 2008;31:230-239.

-36 Guimbal C, Kilimann MW: A Na(+)-dependent creatine transporter in rabbit brain, muscle, heart, and kidney. cDNA cloning and functional expression. J Biol Chem 1993;268:8418-8421.

37 Mak CS, Waldvogel HJ, Dodd JR, Gilbert RT, Lowe MT, Birch NP, Faull RL, Christie DL: Immunohistochemical localisation of the creatine transporter in the rat brain. Neuroscience 2009;163:571-585.

-38 Mellott TJ, Kowall NW, Lopez-Coviella I, Blusztajn JK: Prenatal choline deficiency increases choline transporter expression in the septum and hippocampus during postnatal development and in adulthood in rats. Brain Res 2007;1151:1-11.

-39 Alcaide P, Merinero B, Ruiz-Sala P, Richard E, Navarrete R, Arias A, Ribes A, Artuch R, Campistol J, Ugarte M, Rodriguez-Pombo P: Defining the pathogenicity of creatine deficiency syndrome. Hum Mutat 2011;32:282291.

40 Alcaide P, Rodriguez-Pombo P, Ruiz-Sala P, Ferrer I, Castro P, Ruiz Martin Y, Merinero B, Ugarte M: A new case of creatine transporter deficiency associated with mild clinical phenotype and a novel mutation in the SLC6A8 gene. Dev Med Child Neurol 2010;52:215-217.

-41 Ardon O, Amat di San Filippo C, Salomons GS, Longo N: Creatine transporter deficiency in two halfbrothers. Am J Med Genet A 2010;152A:1979-1983.

42 Battini R, Chilosi A, Mei D, Casarano M, Alessandri MG, Leuzzi V, Ferretti G, Tosetti M, Bianchi MC, Cioni G: Mental retardation and verbal dyspraxia in a new patient with de novo creatine transporter (SLC6A8) mutation. Am J Med Genet A 2007;143A:1771-1774.

-43 Battini R, Chilosi AM, Casarano M, Moro F, Comparini A, Alessandri MG, Leuzzi V, Tosetti M, Cioni G: Language disorder with mild intellectual disability in a child affected by a novel mutation of SLC6A8 gene. Mol Genet Metab 2011;102:153-156.

44 Braissant O, Beard E, Torrent C, Henry H: Dissociation of AGAT, GAMT and SLC6A8 in CNS: relevance to creatine deficiency syndromes. Neurobiol Dis 2010;37:423-433.

45 Braissant 0 , Henry H, Beard E, Uldry J: Creatine deficiency syndromes and the importance of creatine synthesis in the brain. Amino Acids 2011;40:1315-1324.

-46 Hahn KA, Salomons GS, Tackels-Horne D, Wood TC, Taylor HA, Schroer RJ, Lubs HA, Jakobs C, Olson RL, Holden KR, Stevenson RE, Schwartz CE: X-linked mental retardation with seizures and carrier manifestations is caused by a mutation in the creatine-transporter gene (SLC6A8) located in Xq28. Am J Hum Genet 2002;70:1349-1356.

-47 Jensen LR, Chen W, Moser B, Lipkowitz B, Schroeder C, Musante L, Tzschach A, Kalscheuer VM, Meloni I, Raynaud M, van Esch H, Chelly J, de Brouwer AP, Hackett A, van der Haar S, Henn W, Gecz J, Riess O, Bonin M, Reinhardt R, Ropers HH, Kuss AW: Hybridisation-based resequencing of 17 X-linked intellectual disability genes in 135 patients reveals novel mutations in ATRX, SLC6A8 and PQBP1. Eur J Hum Genet 2011;19:717-720.

48 Longo N, Ardon O, Vanzo R, Schwartz E, Pasquali M: Disorders of creatine transport and metabolism. Am J Med Genet C Semin Med Genet 2011;157C:72-78.

49 Mancardi MM, Caruso U, Schiaffino MC, Baglietto MG, Rossi A, Battaglia FM, Salomons GS, Jakobs C, Zara F, Veneselli E, Gaggero R: Severe epilepsy in X-linked creatine transporter defect (CRTR-D). Epilepsia 2007;48:1211-1213.

50 Mercimek-Mahmutoglu S, Connolly MB, Poskitt KJ, Horvath GA, Lowry N, Salomons GS, Casey B, Sinclair G, Davis C, Jakobs C, Stockler-Ipsiroglu S: Treatment of intractable epilepsy in a female with SLC6A8 deficiency. Mol Genet Metab 2010;101:409-412.

51 Puusepp H, Kall K, Salomons GS, Talvik I, Mannamaa M, Rein R, Jakobs C, Ounap K: The screening of SLC6A8 deficiency among Estonian families with X-linked mental retardation. J Inherit Metab Dis 2010;33:S5-11.

52 Rosenberg EH, Martinez Munoz C, Betsalel OT, van Dooren SJ, Fernandez M, Jakobs C, deGrauw TJ, Kleefstra T, Schwartz CE, Salomons GS: Functional characterization of missense variants in the creatine transporter gene (SLC6A8): improved diagnostic application. Hum Mutat 2007;28:890-896. 


\section{Kidney \\ Blood Pressure Research}

\begin{tabular}{|c|c|}
\hline \multicolumn{2}{|c|}{ Kidney Blood Press Res 2014;39:546-554 } \\
\hline $\begin{array}{l}\text { DOI: 10.1159/000368465 } \\
\text { Publisned ontIne: vecember } 082014\end{array}$ & $\begin{array}{l}\text { (c) } 2014 \text { S. Karger AG, Basel } \\
\text { www.karger.com/kbr }\end{array}$ \\
\hline
\end{tabular}

53 Salomons GS, van Dooren SJ, Verhoeven NM, Marsden D, Schwartz C, Cecil KM, DeGrauw TJ, Jakobs C: X-linked creatine transporter defect: an overview. J Inherit Metab Dis 2003;26:309-318.

54 Skelton MR, Schaefer TL, Graham DL, Degrauw TJ, Clark JF, Williams MT, Vorhees CV: Creatine transporter (CrT; Slc6a8) knockout mice as a model of human CrT deficiency. PLoS One 2011;6:e16187.

55 Stockler S, Schutz PW, Salomons GS: Cerebral creatine deficiency syndromes: clinical aspects, treatment and pathophysiology. Subcell Biochem 2007;46:149-166.

56 van de Kamp JM, Mancini GM, Pouwels PJ, Betsalel OT, van Dooren SJ, de Koning I, Steenweg ME, Jakobs C, van der Knaap MS, Salomons GS: Clinical features and X-inactivation in females heterozygous for creatine transporter defect. Clin Genet 2011;79:264-272.

-57 Pathare G, Foller M, Daryadel A, Mutig K, Bogatikov E, Fajol A, Almilaji A, Michael D, Stange G, Voelkl J, Wagner CA, Bachmann S, Lang F: OSR1-Sensitive Renal Tubular Phosphate Reabsorption. Kidney Blood Press Res 2012;36:149-161.

-58 Hosseinzadeh Z, Dong L, Bhavsar SK, Warsi J, Almilaji A, Lang F: Upregulation of peptide transporters PEPT1 and PEPT2 by Janus kinase JAK2. Cell Physiol Biochem 2013;31:673-682.

-59 Warsi J, Hosseinzadeh Z, Dong L, Pakladok T, Umbach AT, Bhavsar SK, Shumilina E, Lang F: Effect of Janus kinase 3 on the peptide transporters PEPT1 and PEPT2. J Membr Biol 2013;246:885-892.

60 Alesutan I, Sopjani M, Dermaku-Sopjani M, Munoz C, Voelkl J, Lang F: Upregulation of Na-coupled glucose transporter SGLT1 by Tau tubulin kinase 2. Cell Physiol Biochem 2012;30:458-465.

61 Henrion U, Zumhagen S, Steinke K, Strutz-Seebohm N, Stallmeyer B, Lang F, Schulze-Bahr E, Seebohm G: Overlapping cardiac phenotype associated with a familial mutation in the voltage sensor of the KCNQ1 channel. Cell Physiol Biochem 2012;29:809-818.

62 Hosseinzadeh Z, Bhavsar SK, Lang F: Downregulation of ClC-2 by JAK2. Cell Physiol Biochem 2012;29:737742.

63 Almilaji A, Szteyn K, Fein E, Pakladok T, Munoz C, Elvira B, Towhid ST, Alesutan I, Shumilina E, Bock CT, Kandolf R, Lang F: Down-regulation of $\mathrm{Na} / \mathrm{K}^{+}$ATPase activity by human parvovirus B19 capsid protein VP1. Cell Physiol Biochem 2013;31:638-648.

-64 Bogatikov E, Munoz C, Pakladok T, Alesutan I, Shojaiefard M, Seebohm G, Foller M, Palmada M, Bohmer C, Broer S, Lang F: Up-regulation of amino acid transporter SLC6A19 activity and surface protein abundance by PKB/Akt and PIKfyve. Cell Physiol Biochem 2012;30:1538-1546.

65 Almilaji A, Munoz C, Hosseinzadeh Z, Lang F: Upregulation of Na+,Cl(-)-coupled betaine/gamma-aminobutyric acid transporter BGT1 by Tau tubulin kinase 2. Cell Physiol Biochem 2013;32:334-343.

66 Pakladok T, Almilaji A, Munoz C, Alesutan I, Lang F: PIKfyve sensitivity of hERG channels. Cell Physiol Biochem 2013;31:785-794.

67 Hosseinzadeh Z, Luo D, Sopjani M, Bhavsar SK, Lang F: Down-regulation of the epithelial Na(+) channel ENaC by Janus kinase 2. J Membr Biol 2014;247:331-338.

68 Hosseinzadeh Z, Sopjani M, Pakladok T, Bhavsar SK, Lang F: Downregulation of KCNQ4 by Janus kinase 2. J Membr Biol 2013;246:335-341.

69 Munoz C, Almilaji A, Setiawan I, Foller M, Lang F: Up-regulation of the inwardly rectifying K(+) channel Kir2.1 (KCNJ2) by protein kinase B (PKB/Akt) and PIKfyve. J Membr Biol 2013;246:189-197.

70 Pakladok T, Hosseinzadeh Z, Lebedeva A, Alesutan I, Lang F: Upregulation of the $\mathrm{Na}(+)$-coupled phosphate cotransporters NaPi-IIa and NaPi-IIb by B-RAF. J Membr Biol 2014;247:137-145.

71 Shojaiefard M, Hosseinzadeh Z, Bhavsar SK, Lang F: Downregulation of the creatine transporter SLC6A8 by JAK2. J Membr Biol 2012;245:157-163.

72 Warsi J, Elvira B, Hosseinzadeh Z, Shumilina E, Lang F: Downregulation of chloride channel ClC-2 by Janus kinase 3. J Membr Biol 2014;247:387-393.

73 Mia S, Munoz C, Pakladok T, Siraskar G, Voelkl J, Alesutan I, Lang F: Downregulation of Kv1.5 K channels by the AMP-activated protein kinase. Cell Physiol Biochem 2012;30:1039-1050.

74 Yang L, Cai X, Zhou J, Chen S, Chen Y, Chen Z, Wang Q, Fang Z, Zhou L: STE20/SPS1-related proline/alaninerich kinase is involved in plasticity of GABA signaling function in a mouse model of acquired epilepsy. PLoS One 2013;8:e74614. 